\title{
Kronik ürtikerli hastalarda fibromiyalji sendromu sıklığının değerlendirilmesi
}

\section{Evaluation of the frequency of fibromyalgia in patients with chronic urticaria}

Aslı Hapa, Oya Özdemir*, Sibel Ersoy Evans, Nilgün Atakan, Fatma Inanıcı*

Hacettepe Üniversitesi Tıp Fakültesi Deri ve Zührevi Hastalıklar Anabilim Dalı ve

*Fiziksel Tıp ve Rehabilitasyon Anabilim Dalı, Ankara, Türkiye

\section{Özet}

Amaç: Son yıllarda periferal kutanöz sinir liflerindeki fonksiyon bozukluğunun ürtiker etyolojisinde rol oynayabileceğine dair çalıșmalar mevcuttur. Kronik ağrı sendromların biri olarak kabul edilen fibromiyalji sendromu etyolojisinde de benzer șekilde periferal kutanöz sinir liflerindeki fonksiyon bozukluğu suçlanmaktadır. Bu çalıșmanın amacı kronik ürtikerli hastalarda fibromiyalji sendromu sıklığının belirlenmesi ve bu sıklığın ürtikerin klinik özelliklerinden etkilenip etkilenmediğini göstermekti.

Gereç ve Yöntem: Çalıșmaya 50 kronik ürtikerli hasta ve 48 kontrol dahil edildi. Otolog serum deri testinin yanı sıra ürtikerin hastalık aktivitesini belirlemek amacıyla ürtiker aktivite skoru (ÜAS) hesaplandı. Fibromiyalji sendromu tanısı ise 1990 Amerikan Romatoloji Koleji kriterleri doğrultusunda konuldu. Hastalar ayrıca hastalık süresine ve ÜAS skorlarına göre ikișer gruba ayrılarak fibromiyalji sendromu sıklı̆̆ı açısından incelendi.

Bulgular: Kronik ürtikerli hastaların \%26'sında, kontrol grubunun ise $\% 20,8^{\prime}$ inde fibromiyalji sendromu olduğu tespit edildi ve iki grup arasında anlamlı fark saptanmadı $(\mathrm{p}=0,715)$. Otolog serum deri testi pozitif olan hastalar ile negatif olan hastalar arasında da fibromiyalji sendromu sıklığı açısından anlamlı farklılık yoktu. ÜAS skorlarına (Grup 1= ÜAS <5, Grup 2 ÜAS $\geq 5$ ) göre iki gruba ayrılan hastalar arasında da fibromiyalji sendromu sıklı̆ı açısından anlamlı fark saptanmadı $(p=0,197)$. Ayrıca hastalar hastalık süresine göre değerlendirildiğinde de (grup $1=$ hastalık süresi<1 yıl, grup $2=$ hastalık süresi $\geq 1$ yıl) fibromiyalji sendromu sıklığı açısından anlamı farklılık yoktu $(p=0,645)$.

Sonuç: Bu çalıșma sonucunda literatürde yakın zamanda yapılmıș olan bir çalıșmanın aksine kronik ürtikerde fibromiyalji sendromu sıklığının artmadığı ve bu sıklığın ürtiker șiddetinden, hastalık süresinden ve otolog serum deri pozitifliğinden etkilenmediği gösterilmiștir. (Türkderm 2012; 46: 202-5)

Anahtar Kelimeler: Kronik ürtiker, fibromiyalji, sıklık

\section{Summary}

Background and Design: In recent years, there are studies about the role of dysfunctioning of the peripheral cutaneous nerve fibers in the etiology of chronic urticaria. Similarly to urticaria, dysfunctioning of peripheral cutaneous nerve fibers was also accused in the etiology of fibromyalgia syndrome which is considered to be the one of the chronic pain syndromes. The aim of this study was to assess the frequency of fibromyalgia syndrome in patients with chronic urticaria and to show whether this frequency was affected by clinical findings of urticaria. Material and Method: Fifty patients with chronic urticaria and 48 controls were included into the study. The autologous serum skin test was performed and urticaria activity score (UAS) was calculated for the evaluation of the severity of the disease. The diagnosis of fibromyalgia syndrome was made in accordance with the American College of Rheumatology 1990 criteria. The patients were divided according to disease duration into 2 groups and according to UAS into two groups.

Results: $26 \%$ of patients with chronic urticaria and $20.8 \%$ of controls had fibromiyalgia syndrome and no significant difference was observed between the groups $(\mathrm{p}=0.715)$. There was also no significant difference between patients with positive autologous serum skin test and patients with negative autologous serum skin test. No significant difference was observed in the frequency of fibromyalgia syndrome between the patients either when divided into 2 groups according to UAS or when divided into two group according to disease duration ( $p=0.197$ and $p=0.645$, respectively).

Conclusion: In conclusion, in contrast to a recently reported study, we observed that the frequency of fibromyalgia syndrome was not increased in chronic urticaria and this frequency was not affected by the severity of urticaria, disease duration and positive autologous serum skin test. (Turkderm 2012; 46: 202-5)

Key Words: Chronic urticaria, fibromyalgia, frequency

Yazışma Adresi/Address for Correspondence: Dr. Aslı Hapa, 1 Hacettepe Üniversitesi Tıp Fakültesi Deri Ve Zührevi Hastalıklar Anabilim Dalı, Ankara, Türkiye Tel.: +90 3123051704 E-posta: draltaykan@yahoo.com Geliş Tarihi/Received: 07.01.2012 Kabul Tarihi/Accepted: 22.03.2012 


\section{Giriş}

Fibromiyalji sendromu, hastanın semptomlarını açıklayacak belirgin bir organik hastalık yokluğunda, fizik muayenede palpasyonla hassas noktaların tespit edildiği kronik yaygın ağrı sendromlarından biridir Fibromiyalji sendromunun normal toplumdaki prevalansı \%1-4 arasında değişmekte olup, çoğunlukla kadınlarda görülmektedir2. Bununla birlikte, bu sendromun dismenore, migren, depresyon, irritabl barsak sendromu gibi etyolojisinde emosyonel faktörlerin önemli rol oynadığı birçok hastalıkla birlikte olduğu bilinmektedir³. Benzer şekilde, psöriyasis ve sistemik lupus eritematozus gibi dermatolojik hastalıkların varlığında fibromiyalji sendromunun sıklığının arttığı gösterilmiştir4,5.

Etyolojisi henüz tam olarak açığa çıkarılamamış olan bu hastalığın son yıllarda yapılan çalışmalarda nörojenik inflamasyonun da eşlik ettiği nöropatik ağıı sendromlarından biri olduğu görüşü ortaya atılmıştır6,7. Bu nörojenik inflamasyonun yine etyolojisi benzer şekilde tam olarak açıklığa kavuşmamış olan kronik ürtiker patogenezinde de rol oynayabileceğine dair çalışmalar mevcuttur8. Bu ortak hipotezden yola çıkarak yakın dönemde yapılmış olan bir çalışmada, kronik ürtikeri olan hastalarda fibromiyalji sendromu sıklığı normal toplumdan çok daha yüksek bulunmuştur9. Ayrıca, fibromiyalji sendromunda olduğu gibi kronik ürtiker etyolojisinde de emosyonel stresin önemli bir rol oynadığı düşünülmektedir10. Ancak, kronik ürtiker ile fibromiyalji sendromunun birlikteliğini inceleyen İngilizce literatürde sadece bir çalışma mevcuttur ${ }^{9}$. Yukarıda bahsi geçen bilgiler doğrultusunda, biz bu çalışmada hem etyolojide hem de patogenezde ortak noktaları olduğu bilinen bu iki hastalığın birlikteliğini araştırmayı ve bu birlikteliğin hastalık şiddetinden etkilenip etkilenmediğini belirlemeyi amaçladık.

\section{Gereç ve Yöntem}

Deri ve Zührevi Hastalıklar polikliniklerine Haziran 2010 ve Haziran 2011 tarihleri arasında başvuran kronik ürtikerli 50 hasta (37 kadın,13 erkek) ile cinsiyet bakımından eşleştirilmiş 48 kontrol (36 kadın, 12 erkek) dahil edildi. Çalışmaya $>18$ yaş, en az 6 haftadır tekrarlayan ürtikeryal döküntülerin olan hastalar alınırken, kontrol grubu ise kronik ürtiker dışında herhangi bir deri hastalığı nedeniyle başvuran hastalardan oluşturuldu. Çalışmadan dışlanma kriterleri ise psöriyasis ve eşlik eden bir romatolojik hastalığın varlığı, fiziksel ürtiker varlığı olarak belirlendi. Çalışmanın etik kurul onayı Hacettepe Üniversitesi Senatosu Etik Komisyonundan alındı.

Tüm hastalar ilaç kullanımı, ailesel ve kişisel atopi öyküsü, hastalık süresi, egzersiz, stres, sıcak soğuk gibi ürtikeri tetikleyici faktörler açısından sorgulandı. Elli hastanın 48'ine otolog serum deri testi uygulandı ${ }^{11}$. Hastalık aktivitesini belirlemek üzere ürtiker aktivite skoru (ÜAS) hesaplandı ${ }^{12}$. ÜAS belirlerken kronik ürtikerli hastalar geçen hafta çıkan yaklaşık ürtikeryal plak sayısını ( 0 =hiç; $1=$ hafif, $\leq 20$ adet plak/24 saat; $2=$ orta, $21-50$ adet plak $/ 24$ saat; $3=$ şiddetli, $>50$ adet plak $/ 24$ saat) ve kaşıntı şiddetini ( $0=$ yok, $1=$ hafif, $2=$ orta, $3=$ şiddetli) değerlendirdiler. Fibromiyalji tanısına yönelik fizik muayene 5 yıllık tecrübesi olan bir Fizik Tedavi ve Rehabilitasyon uzman hekimi tarafından (OÖ) gerçekleştirildi. Tüm katılımcılara son 3 ayda yaygın ağrı şikayeti olup olmadığı soruldu. Eğer ağrı mevcutsa, süresi ve şiddeti kaydedildi. Fizik muayenede 1990 yılı Amerikan Romatoloji Koleji tarafından belirlenen fibromiyalji kriterleri doğrultusunda 18 hassas nokta palpasyonla değerlendirildi. Fibromiyalji tanısı alan hastalardan klinik şiddeti ve fonksiyonel kısı tlamayı belirlemek amacıyla 10 sorudan oluşan ve Türkçe versiyonunun güvenirliliği ve geçerliliği gösterilmiş olan Fibromiyalji Etki Anketi (FEA)'ni doldurmaları istendi13.

İstatistiksel analizler SPSS versiyon 11,5 paket programı kullanılarak gerçekleştirildi. Tanımlayı c istatistiksel analizlere ilave olarak hasta ve kontrol grupları arasında yapılan karşılaştırmalarda kesikli değişkenler için ki kare testi, sürekli değişkenler için bağımsız gruplarda t testi kullanıldı. Fibromiyalji sendromu tanısı konulan hasta ve kontrol grubuna ait değişkenler ise Mann Whitney $U$ testi ile karşılaştııldı. Ayrıca otolog serum deri testi, ÜAS ve hastalık süresine göre kronik ürtikerli hastaların gruplara ayrılmasıyla yapılan karşılaştırmalarında da ki kare testi kullanıldı. P değerinin 0,05'in altında olması durumunda sonuçlar istatistiksel olarak anlamlı kabul edildi. Tüm sonuçlar ortalamaıstandart sapma olarak ifade edildi, standart sapması çok yüksek olan değişkenler için ortanca değerler de belirtildi.

\section{Bulgular}

Hasta ve kontrol grubunun yaş ortalamaları sırasıyla 39,1 $\pm 11,4$ yıl (aralık, 19-72) ve 37,0 012,8 yıl (aralık, 19-64) olup iki grubun yaşları birbirine benzerdi $(p=0,279)$. Kronik ürtikerli hastaların $\% 26$ sında $(n=13)$, kontrol grubunun ise $\% 20,8^{\prime}$ inde $(n=10)$ fibromiyalji sendromu olduğu tespit edildi. Fibromiyalji sendromu sıklığı açısından hasta ve kontrol grubu arasında istatistiksel olarak anlamlı farklılık mevcut değildi $(p=0,715)$. Otolog serum deri testi tüm hastaların $\% 53$ ünde $(n=25)$ pozitif olarak belirlendi. Otolog serum deri testi pozitif olan hastaların $\% 28^{\prime}$ inde $(n=7)$, negatif olan hastaların ise \%27,3'ünde fibromiyalji sendromunun olduğu gözlendi. Bu iki grup arasında fibromiyalji sendromu sıklığı açısından anlamlı farklılık yoktu $(p=0,570)$. ÜAS<5 olan hastaların 4'üne (\%16), ÜAS $\geq 5$ olan hastaların 9'una (\%36) fibromiyalji sendromu tanısı konuldu. Hastalık sürelerine göre bakıldığında ise; <1 yıl kronik ürtikeri olanların 4'ünde (\%20), $\geq 1$ yıl kronik ürtikeri olanların 9'unda (\%30) fibromiyalji sendromu mevcuttu. Hem ÜAS'a $(p=0,197)$ hem de hastalık süresine $(p=0,645)$ göre gruplar arasında fibromiyalji sendromunun sıklığı açısında istatistiksel olarak belirgin bir fark olmadığı tespit edildi. Fibromiyalji sendromu tanısı alan hasta ve kontrol grubuna ait demografik bulgular:

Fibromiyalji sendromu tanısı alan kronik ürtikerli hastaların ortalama yaşı $44,2 \pm 14,1$ yıl (aralık, 22-72), kontrol grubunun ise 48,1 $\pm 8,4$ yıldı (aralık, 31-59). Her iki grupta da tüm hastalar kadınlardan oluşmaktaydı. Hem hasta hem kontrol grubunda yaygın ağrı süresi oldukça geniş aralıkta dağılmakta olup ortanca değerleri sırasıyla 2 yıl ve 2,5 yıldı. Hasta grubunda hassas nokta sayısı ortalaması 14,7 $\pm 2,6$ iken kontrol grubunda $15,2 \pm 2,7$ olarak bulundu. FEA skorlarının ortalaması ise hasta grubunda $60,9 \pm 12,9$, kontrol grubunda $60,4 \pm 14,6$ olarak belirlendi. Tüm bu değişkenler bakımından iki grup arasında istatistiksel olarak anlamlı bir fark bulunmadı.

\section{Tartışma}

Kronik ürtiker, ürtiker plaklarının 6 haftadan uzun sürmesi olarak tanımlanmaktadır14. Patogenezi tam olarak bilinmeyen bu hastalığın etyolojisinde çok çeşitli faktörler suçlanmaktadır. Hastaların \%45'inde saptanan otoimmün etyoloji en çok üzerinde durulan faktörlerden biridir ${ }^{15}$. Kronik ürtikerli hastalarda artmış oranda tiroid otoantikorlarının gösterilmesi de bu durumu desteklemektedir ${ }^{16}$. Bu bilgilere ilaveten, 
Grattan ve ark. tarafından derideki mast hücrelerine karşı oluşan otoantikorlar otolog serum deri testi ile hastaların \%30'unda gösterilmiştir ${ }^{17}$. Kronik ürtikere benzer şekilde fibromiyalji sendromunda da otoimmün hastalıklarla birliktelik tanımlanmıştır18.

Son yıllarda derideki immün sistem ve periferik sinir sistemi arasındaki etkileşim merak uyandırmakta ve epidermis bir duyu organı olarak kabul edilmektedir ${ }^{19}$. Bu etkileşimde Langerhans ve mast hücreleri nöroendokrin ve immün sistem arasında anahtar rol oynamaktadırlar20.

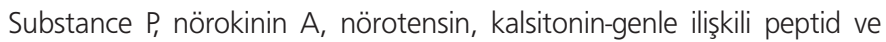
vazoaktif intestinal peptid gibi taşikininler sadece nöronlarda değil ekrin glandlar ve damar duvarları gibi derinin çeşitli bölgelerinde de tespit edilmişlerdir21. Bu nöropeptidlerin derideki monositlerden, keratinositlerden, endotel hücrelerinden, merkel hücrelerinden, fibroblastlardan salındığı ve mast hücrelerinin yanı sıra başka birçok hücre üzerinde etkileri olduğu da gösterilmiştir22. Hatta fibromiyalji sendromu gibi nöropatik ağrının sorumlu tutulduğu hastalıklarda da mast hücrelerinin anahtar rol oynadığını gösteren çalışmalar mevcuttur23. Biz de bu çalışmayı iki hastalığın birlikteliğinde yukarıda bahsi geçen ortak faktörlerin rol oynayabileceğini düşünerek planladık. İngilizce literatürde kronik ürtikerde fibromiyalji sendromu sıklığının araştııılığı bir çalışma mevcuttu. Torresani ve ark.'nın yaptığı bu çalışmada 126 kronik ürtikerli (86 kadın, 40 erkek) hastada fibromiyalji sendromu tanısı bizim çalışmamızda olduğu gibi 1990 Amerikan Romatoloji Koleji kriterleri doğrultusunda konulmuştu. Bu çalışmada, kronik ürtikerli hastaların $89^{\prime}$ unda $(\% 70,6)$ fibromiyalji sendromu tespit edilirken, bu oran kontrol grubunda \%16 olarak belirlenmiş ve aralarında anlamlı düzeyde fark bulunmuştu. Bizim çalışmamızda ise fibromiyalji sendromu sıklığı hasta ve kontrol grubunda sırasıyla \%26 ve \%20,8 olarak belirlendi. Torresani ve ark.'nın çalışmasından farklı olarak, her iki gruptaki fibromiyalji sendromu sıklığı birbirine benzer bulundu. Ayrıca önceki çalışmada, fibromiyalji sendromu tanısı alan kronik ürtikerli hastaların $15^{\prime} \mathrm{i}$ daha önceden fibromiyalji sendromu tanısı almıştı ancak bizim hastalarımızın hepsi yapılan değerlendirme sonucunda tanı aldı. Her iki çalışma otolog serum deri testi pozitifliği açısından karşılaştırıldığında, Torresani ve ark.'nın çalışmasında hastaların yaklaşık 1/3'ünde otolog serum deri testi pozitifken bizim hastalarımızın yarısında bu test pozitifti. Otolog serum deri testi pozitif olan hastalarda fibromiyalji sendromu sıklığı ise Torresani ve ark.'nın çalışmasında \%81, bizim çalışmamızda \%28 olarak tespit edildi. Patogenezde her 2 hastalığın da etyolojisinde otoimmünite suçlanmaktadır. Torresani ve ark. bunu destekler biçimde otolog serum deri testi pozitif hastalarda fibromiyalji sıklığını daha da yüksek bulmuşlardır. Ancak bizim çalışmamızda bu hipotezi destekleyecek bir veri elde edilmemiştir. Tüm bu bulguların yanı sıra, biz önceki çalışmadan farklı olarak fibromiyalji sendromu sıklığının hastalık şiddetinden etkilenip etkilenmediği de araştırdık. Fakat, bu amaçla ÜAS ve hastalık süresine göre gruplara ayrılan hastalar arasında fibromiyalji sendromu sıklığı açısından herhangi bir farklılık saptamadık.

Hasta sayımızın ilk çalışmaya oranla daha düşük olmasına rağmen, her iki çalışmada fibromiyalji sendromu sıklığı sonuçlarındaki farkılı̆̆ın başlıca nedeninin tanı aşamasındaki farklılıktan kaynaklanabileceğini düşünmekteyiz. Torresani ve ark. fizik muayeneyi bu konuda eğitim aldıktan sonra kendileri gerçekleştirmiş olmakla birlikte, bizim çalışmamızda tanıda standardizasyonu sağlamak amacıyla muayene konusunda 5 yıllık deneyimi olan bir Fizik Tedavi ve Rehabilitasyon uzman hekimi tarafından gerçekleştirildi. Yine aynı çalışmada 15 kronik ürtiker hastasının daha önceden fibromiyalji sendromu tanısı almış olmasının da seçilen hasta populasyonunda fibromiyalji sendromu sıklığının artışına sebep olabileceğini düşünmekteyiz.

Çalışmamızda kronik ürtikerli hastalarda fibromiyalji sıklığında artış tespit edilmemesine rağmen, kontrol grubunda fibromiyalji sıklığının (\%20) toplum insidansına (\%1-4) göre daha fazla olduğu tespit edildi. Bu farklılı̆ın seçilen kontrol grubunda hasta grubu ile orantılı olmak adına kadın cinsiyetin ön planda seçilmesine bağlı olabileceğini düşünmekteyiz çünkü kadın cinsiyette fibromiyalji (\%2) erkek cinsiyete göre daha fazla görülmektedir2.

Sonuç olarak, vaka-kontrol olarak düzenlenen bu pilot çalışmada kronik ürtikerli hastalarda fibromiyalji sendromu sıklığının normal populasyona göre yüksek olmakla birlikte, kontrol grubuyla benzer olduğu belirlendi. Ayrıca, bu sıklığın hastalık süresinden, ürtiker aktivitesinden ve otolog serum deri testi pozitifliğinden etkilenmediğini bulundu. Her ne kadar önceki çalışmada, kronik ürtiker ve fibromiyalji sendromunun yüksek orandaki birlikteliği nöropatik deri inflamasyonu hipoteziyle açıklanmaya çalışısa da, bizim bu çalışmada elde etmiş olduğumuz sonuçlar bu görüşü desteklememektedir. Gerçekten de, fibromiyalji sendromunun gelişiminde tek bir nedeni öne sürmek oldukça güçtür. Günümüzde halen, bu sendromun patofizyolojisine otonomik ve nöroendokrin sistem fonksiyon bozuklukları, uyku bozuklukları, genetik etkiler, fiziksel ve psikososyal stres gibi çevresel tetikleyiciler başta olmak üzere çok sayıdaki faktörün katkıda bulunduğu düşünülmektedir24. Bu bilgiler doğrultusunda iki hastalığın birlikteliğinin açıklığa kavuşması için daha fazla hasta sayısı ile yeni çalışmalara ihtiyaç olduğunu düşünmekteyiz.

\section{Kaynaklar}

1. Wolfe $F$, Smythe HA, Yunus $M B$, et al: The American Collage of Rheumatology 1990 criteria for the classification of fibromyalgia. Report of the multicenter criteria committee. Arthritis Rheum 1990;33:160-72.

2. Goldenberg DL: Fibromyalgia and related syndromes. In: Hochberg MC, Silman AJ, Smolen JS, Weinblatt ME, Weiman MH, eds. Rheumatology. 3rd edition. Philadelphia: Mosby;2003. p.701-712

3. Van Houdenhove $B$, kempke $S$, luyten P: Psychiatric aspects of chronic fatigue syndrome and fibromiyalgia. Curr Psychiatry Rep 2010;12:208-14.

4. Thune PO: The prevalence of fibromiyalgia among psoriasis patients. Acta Derm Venereol 2005;85:33-7.

5. Staud RO Are patients with systemic lupus erythematosus at increased risk for fibromyalgia? Curr Rheumatol Rep 2006;8:430-5.

6. Littlejohn $\mathrm{GO}$, Weinstein C, Helme RD: Increased neurogenic inflammation in fibrositis syndrome. J Rheumathol 1987;14:1022-25.

7. Kim SH,Kim D, Oh D: Characteristic changes of unmyelinated nevre fibres in the skin of the patients with fibromiyalgia. Arthritis Rheum 2006;54:126.

8. Steinhoff $M$, Stander $S$, Seeliger $S$, et al: Modern aspects of cutaneous neurogenic inflammation. Arch Dermatol 2003;139:1479-88.

9. Torresani C, Bellafiore S, De Panfilis G: Chronic urticaria is usually associated with fibromyalgia syndrome. Acta Derm Venereol 2009;89:389-92.

10. Chung MC, Symons C, Gilliams J, Kaminski ER: Stress, psychiatric comorbidity and coping in patients with chronic idiopathic urticaria. Psychol Health 2010;25:477-90.

11. Sabroe RA, Grattan CE, Francis DM, et al: The autologous serum skin test:a screening testfor autoantibodies in chronic idiopathic urticaria. Br J Dermatol 1999;140:446-52.

12. Zuberbier T, Bindslev-Jensen C, Canonica W, et a: EAACI/GA2LEN/EDF guideline:definition, classification and diagnosis of urticaria. Allergy 2006;61:316-20.

13. Sarmer S, Ergin S, Yavuzer G: The validity and reliability of the Turkish version of the Fibromyalgia Impact Questionnaire. Rheumatol Int 2000;20:9-12.

14. Bolognia J, Jorizzo JL, Rapini RP. Dermatology: In:Grattan CEH, Black AK eds. Urticaria and angioedema, 2rd edition, Spain:Mosby-Elsevier, 2008,261-76.

15. Tong L, Balakrishnan G, Kochan J, Kinet J, Kaplan A: Assessment of autoimmunity in patients with chronic urticaria. J Allergy Clin Immunol 1997;99:461-5. 
16. Leznoff A, Sussman FL: Syndrome of idiopathic chronic urticaria and angioedema with thyroid autoimmunity : a study of 90 patients. J Allergy Clin Immunol 1989;84:66-71.

17. Grattan $\mathrm{CEH}$, Wallington TB, Wurin RP, Kennedy CTC, Bradfield JW: A serological mediator in chronic idiopathic urticaria. A clinical, immunological, and histological evaluation. Br J Dermatol 1986;114:583-90.

18. Staines DR: Is fibromiyalgia is an autoimmun disorder of endogenous vasoactive peptides? Med Hypothesis 2004;62:662-5.

19. Boulais N, Misery L: The epidermis: a sensory organ. Eur J Dermatol 2008;18:119-27.
20. Misery L: Langerhans cells in the neuro-immuno-cutaneous system.ç J Neuroimmuno-cutaneous system. J Neuroimmunol 1998;89:83-7.

21. Girolomoni G, Gianetti A: Neuropeptides and the skin: morphological functional and physiopathological aspects. G Ital Dermatol Venereo 1989;124:121-40.

22. Lotti T, Hautmann G, Panconesi E: Neuropeptides in skin. J Am Acad Dermatol 1995;33.482-96.

23. Kim SH: Skin biopsy findings: implications for the pathophysiology of fibromiyalgia. Med Hypothesis 2007:33:827-8.

24. Bradley LA: Pathophysiology of fibromyalgia. Am J Med 2009;122(12 Suppl):22-30. 